\title{
1 次元有限要素法による大規模立体骨組の複合非線形解析 COMBINED NON-LINEAR ANALYSES OF A LARGE SPACE FRAME USING ONE-DIMENSIONAL FINITE ELEMENT METHOD
}

\author{
堀 昭夫*, 笹川 明** \\ Akio HORI and Akira SASAGAWA
}

\begin{abstract}
Materially and geometrically non-linear analysis of the tested models for a large space frame is presented based on one-dimensional finite element method. The analytical results have been confirmed to agree sufficiently with the experimental ones up to a large deformed state. Coupled chord bucklings and complicated collapsed states were simulated well. The analytical results of the partial models have shown that coupled buckling between several chords appears asymmetric because of the difference of axial forces allowed by adjacent members. Except for whole buckling-like phenomena, it is possible to analyze a large and complicated space frame with elasto-plastic coupled bucklings up to a large deformed state.
\end{abstract}

Keywords: combined non-linear analysis, space frame, large frame, elasto-plastic buckling, coupled buckling, fiber 複合非線形解析、立体骨組、大規模骨組、弾塑性座屈、連成座屈、線素

\section{1.はじめに}

剛接立体骨組に関する、材料非線形性および幾何学的非線形性の 両方を考慮した複合非線形解析は、これまでにいくつかなされてい る。最近の解析では、水渡・多田による一般硬化塑性ヒンジモデル と増分摂動法を用いた2層立体トラス平板の解析 ${ }^{1)}$ 、加藤らによる 部材の両端および中央での塑性化を考慮した剛接合単層ラチスドー

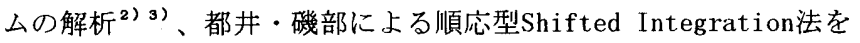
用いた大規模建物の解析 (等があげられる。また剛接骨組ではない が、システムトラス等を模擬した複合非線形解析では、加藤らの解 析 $^{5)}$ や鈴木 ・ 小河らの解析 ${ }^{()}$等があげられる。また修行らによる半 剛接骨組の複合非線形解析 ${ }^{7}$ も報告されている。さらに骨組解析法 による部材の解析に、北田・上谷 $\cdot$ 大崎による柱部材の解析 ${ }^{8)}$ 等が. ある。なおピン接合の2層立体トラスの解析は数が多く、例えば $\mathrm{Hi} 115^{9)}$ 、和田 $5^{(0)}$ 、多田 $5^{11)}$ 、石川 ${ }^{12)}$ の解析がある。

しかし筆者らの立体トラス模型実験 ${ }^{13)}{ }^{14)}$ で観察されたような、 互いに剛接された部材が連成して弾塑性座屈する現象を模擬した立 体解析はあまり見あたらない。この上うな座屈を含む骨組を、部材 の両端および中央だけで塑性化を考慮して ${ }^{12}$ 2)3）5）解析すると、骨 組全体の変形が必ずしも正しく評価されない。

一方、複合非線形解析では、要素の負荷・除荷を適切に仮定しな いと解が得られないという問題があり、上谷・中村・森迫・石田に より整合剛性行列の形成法 ${ }^{13)}{ }^{18)}$ が発表されている。ただしこの方 法を用いた立体骨組の複合非線形解析は今のところ発表されていな い。上記の水渡・多田の解析 ${ }^{1)}$ は、最終的には循環剛性選択過程 ${ }^{15)}$
に宿って解析を終了している。立体骨組の複合非線形解析では、解 析対象が複雑もしくは大規模になるほど、整合剛性を求める困難さ が増えると推察される。また整合剛性を常に用いて解析寸ると、あ る要素で必要となった小さな増分に骨組全体の増分が依存してしま い、大規模立体骨組を解析するには、現状の実用レベルの数值解析 能力で整合剛性を厳密に守ることは困難と考えられる。この観点か ら、部材を材軸方向に6分割して各断面で線素の応力一歪関係を追 跡する部材モデルを用いるとともに、部材内の解析で整合剛性がう まく見つからない場合には試行した中から適当な剛性を選択し、部 材内では増分を小さくするが骨組全体では増分を大きく設定する、 立体骨組の複合非線形解析法を提案した ${ }^{17}$ 。ただし全体座屈的な 現象は解析対象から除いた。本論では、この解析法を改良して、解 析法の提案 ${ }^{17}$ では行わなかった大規模立体骨組に対する複合非線 形解析を行う。解析対象は大規模立体トラス模型実験 ${ }^{13)}{ }^{14)}$ とし、 実験結果と解析結果の比較により大規模立体骨組に対寸る解析法の 妥当性を検討する。また解析における剛接立体トラスの部材座屈举 動についても検討する。

\section{2. 解析方法}

解析方法は立体骨組の複合非線形解析法 ${ }^{17)}$ によった。ただし2.2 で述べるように骨組全体の増分解析方法を若干変更した。解析方法 の概略を以下に簡単に記す。なお解析法 ${ }^{27)}$ と同様に、大規模骨組 への適用性を考えて骨組全体の增分を大きくした解析結果が直ちに 正解である理論的な保証はない。しかし仮に釣合を满足する解が1
* 八ザマ技術研究所 主任研究員・博士 (工学)

** 信州大学工学部社会開発工学科 教授・只博
Chief Research Engineer, T.R.I., Hazama Corp., Dr. Eng.

Prof., Dept. of Architecture and Civil Engineering, Faculty of Engineering, Shinshu Univ., Dr. Eng. 
つであるとすれば、解に振動・発散がなく不釣合力が小さければ、 骨組全体の增分を大きくしても大きな問題はないと考える。

\section{1 部材モデル}

部材は、両端の剛域を除いた部分を材軸方向に6つの要素（以下、 小要素と呼ぶ) に分割してモデル化した。ただし各小要素の長さは 部材内法の $1 / 6$ とした。部材モデルの概要を図一1に示す。小要素内 では断面力と柔性が要素軸に沿って直線分布するとした。このとき せん断変形を無視すると、小要素の剛性が両端の断面柔性から容易 に得られる。両端の断面柔性は、断面を線素に置換して求め、線素 の応力ー歪関倸江模型実験 ${ }^{13)}$ で定めた拡張されたRamberg-0sgood モデル(図一2)によった。断面の線素分割数は 8 とした。小要素のね じりは純ねじりとし、履歴モデルを線素の塑性化とは独立で線素の 耐力曲線と相似な逆行型（除荷されても載荷曲線上を戻るモデル） に簡略化した。小要素の幾何剛性は、軸力、2方向の曲げモーメン ト、およびるじりモーメントからなる両端の断面力が保たれた状態 での、剛体移動、両端間距離の増減、および両端それぞれの要素軸 回りの回転、を考慮した。節点座標および要素座標系の更新は幾何 剛性と対応するように行い、小要素両端での要素軸回り回転角の相 違は、両端で断面の柔性・歪・态力を座標変換して考慮した。なお 要素軸回りの回転で、小要素端の曲げ回転角の累積值を無視すると 適合条件が満たされない。このため曲げ回転角の増分は、累積值と 要素軸回りの回転角增分を考慮して求めた。

\section{2 骨組全体の増分解析}

骨組全体の系 (以下、全体系と呼ぶ）の増分解析は、解析法 ${ }^{17}$ ) と同様に、全体系の増分をある程度大きく設定して、不釣合力の解 消を次ステップ以降で行った。ただし本論では以下の変更を加えた。

全体系の解析で求めた変位増分により部材の除荷が新たに生じる 場合に、部材の線素剛性を変更して全体系の変位增分を求め直すが、 その回数を 1 回 $^{17)}$ ではなく 5 回以内に変更した。また上記の部材の 除荷の判定は、簡単のため線素の歪増分によらずに、部材への外力 仕事増分を部材体積および材料強度で除した值がある值以下で、接 線哃性が低下した線素を有する場合に、部材の除荷が起きたと判定 しているが、その值を文献 ${ }^{17)} の-10^{-6}$ から-10-5 以下に変更した。 以上の変更は、後述の「4. 直交方向試験の解析」に関寸る試計算に

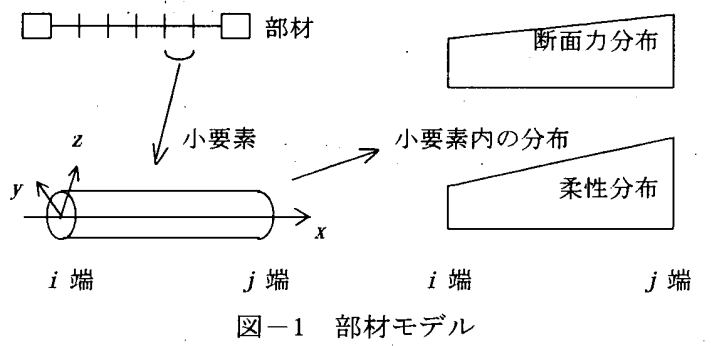

おいて、解の振動・発散がより少なかったことを参考に行った。な お過去の解析結果 ${ }^{11}$ や後述の「3. 非対称鉛直力試験の解析」で示 す解析結果には、上記変更による差異は特になかった。また部材へ の外力仕事増分が正で線素の除荷が生じる現象は、部材の除荷では 考慮せず、部材内の増分解析を通じて考慮される。

\section{3 線素の剛性選択}

部材内の解析では、部材内の節点における力の釣合を満足するよ う増分の大きさを調節して、全体系で計算された部材端変位に到達 するまで増分解析を行った。線素の負荷・除荷の仮定には、循環剛 性選択過程 ${ }^{13)}$ に陥った場合でも、多くない回数の試行の中から相 対的に適切と思われる仮定を選択する試行的な剛性選択法 ${ }^{17)}$ を用 いた。選択法の概略を簡単に記す。(1)歪増分の向きが仮定と整合し ない線素があれば、その線素の仮定を変更して試行する。(2)循環剛 性選択過程に陥った場合は、除荷発生を仮定す心゙き線素が1つであ るとして多くない回数の試行を行う。(3)以上で整合剛性が得られな い場合は、不整合指標と不釣合軸力指標の和が最も小さい剛性仮定 を選択する。ここに不整合指標は、整合しない線素の歪増分の絶対 值に弾性係数と線素断面積を掛けた合計值とし、不釣合軸力指標は、 全体系の解析で仮定した部材剛性による軸力増分と、歪増分から求 めた軸力増分の差の絶対值である。

\section{3. 非対称鉛直力試験の解析}

3. 1 実験概要

非対称鈆直力試験については文献 ${ }^{13)} に$ 詳しいので、簡単に記す。 試験体は、試設計 ${ }^{18)}$ の部分屋根である2層立体トラスを縮尺 $1 / 100$ に全型縮小した模型試験体である。試験体の全体形状を図一3に示 す。ライズスパン比は約 0.20 、部材総数は約 2200 である。試験体架 構は、2本の下弦材と1本の上弦材を有する主トラス、および主トラ ス間を相互につなぐ材から構成される。主トラスは脚部では片側あ たり9本あるが、上部では 5 本、頂部では3 本に本数が減少する。主 トラス間をつなぐラチスは、基本的には1列おきに配されている (同図 (b)参照)。試験体部材には、断面および素材試験結果を表 -1に示寸計6種の銅管を使用した。'加力は、同図 (b) の左半分の下

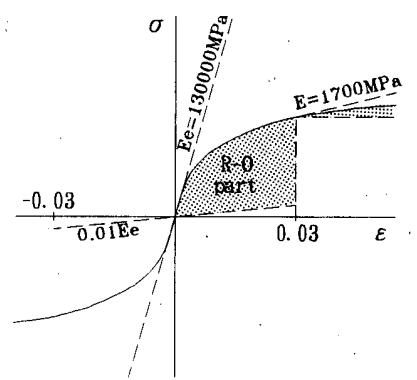

(a) skelton curve

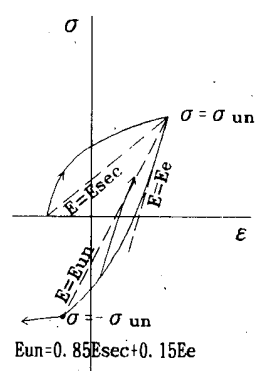

(b) unloading curve 図-2 線素の忘力ー歪モデル

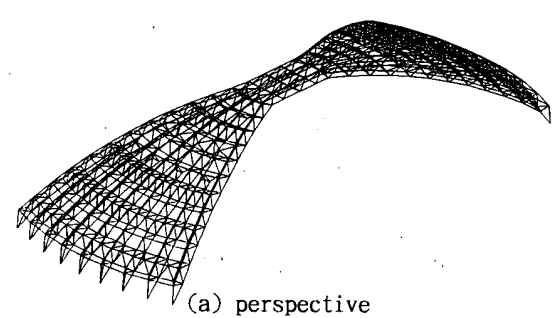

(a) perspective

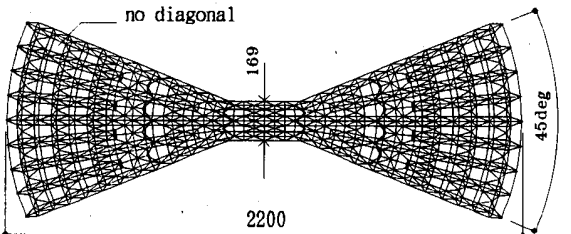

(b) plan

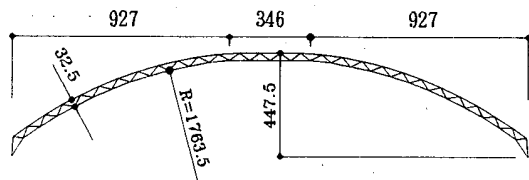

(c) general elevation

図-3 試験体の全体形状 
弦材面の計28点に対して、試設計での重量分布や負担面積を参考に、 トーナメント方式により下向鉛直力を単調載荷した。

3. 2 解析結果および実験との比較

非対称鉛直力試験に対する解析は、実験結果が平面図 (図-3(b)) の上下方向にほぼ対称だったことから、1/2モデルを用いて解析し た。境界条件は柱脚を固定し、1/2モデルにするための切断面で同 面外一の変形を拘束した。なお解析では、実験時のトーナメントを 1つの要素に置換して、トーナメント元端の鉛直変位を制御した。 初期不整は無視した。

図ー4に実験および解析の荷重一変位曲線を実線および破線で示 す。ただし荷重はトーナメント元端の荷重で、変位は試験体を1つ

表-1 試験体の部材断面と素材試験結果

\begin{tabular}{|c|c|c|c|c|c|c|}
\hline 公称断面 & $\begin{array}{r}\text { 外 径 } \\
(\mathrm{mm})\end{array}$ & $\begin{array}{r}\text { 管 } \text { 厚 } \\
\\
(\mathrm{mm})\end{array}$ & \begin{tabular}{|l} 
弾性 \\
倸数 \\
$(\mathrm{Ma})$
\end{tabular} & $\begin{array}{l}0.2 \% \\
\text { 而足 } \\
(\mathrm{MPa})\end{array}$ & \begin{tabular}{|l} 
最 大 \\
而 \\
$(\mathrm{MPa})$
\end{tabular} & $\begin{array}{r}\text { 伸 び } \\
(\%)\end{array}$ \\
\hline$\phi-5.0 \times 0.5$ & 4.97 & 484 & 125000 & 47.5 & 229 & 56 \\
\hline$\phi-4.0 \times 0.5$ & 3.97 & 502 & 130000 & 49.3 & 231 & 53 \\
\hline$\phi-3.5 \times 0.5$ & 3.46 & 473 & 127000 & 47.2 & 230 & 51 \\
\hline$\phi-3.5 \times 0.3$ & 3.48 & 268 & 120000 & 58.4 & 232 & - \\
\hline$\phi-2.5 \times 0.25$ & 2.48 & 221 & 112000 & 44.0 & $>217$ & - \\
\hline$\phi-2.0 \times 0.25$ & 1.97 & 238 & 117000 & 56.3 & 241 & 44 \\
\hline
\end{tabular}

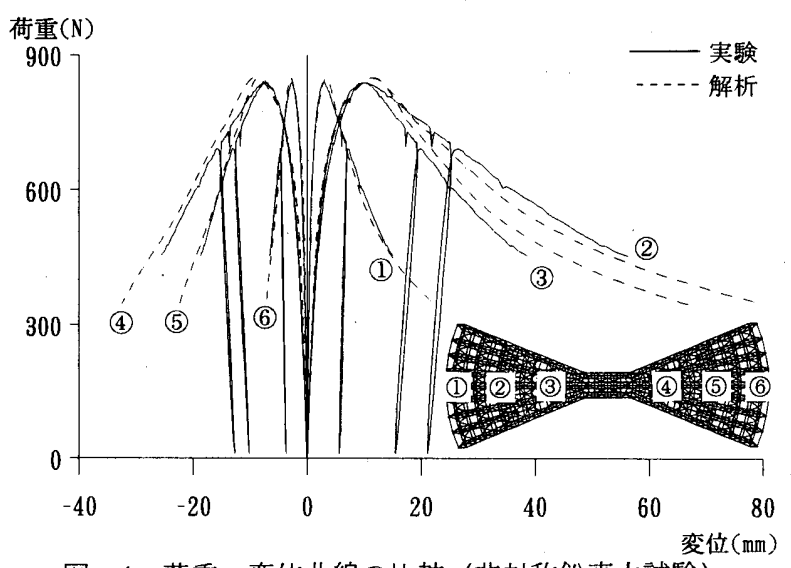

図 -4 荷重一変位曲線の比較（非対称鉛直力試験）

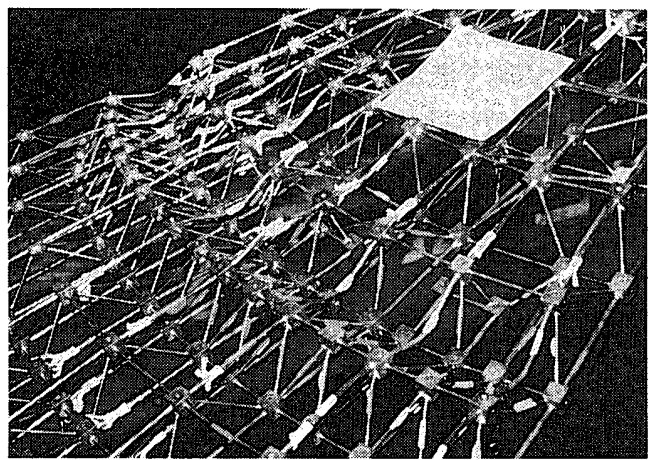

(a) 全景

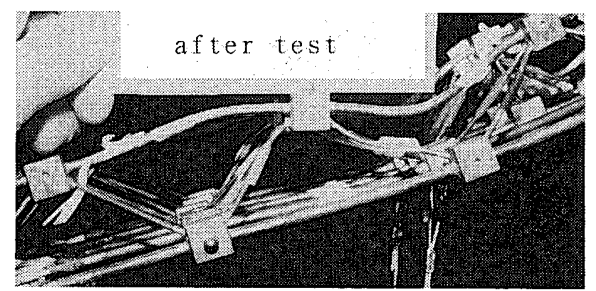

(b) 詳細

写真 -1 実験の上弦材の座屈
の球殼として見たときの球中心方向への変位を示す。また図中(1) (6)は、図中右下の平面図に示した位置での変位である。図を見ると 解析結果 (破線) は実験結果 (実線) と非常に良く一致している。最大 荷重も解析值849Nが実験值839Nとほとんど一致した。ただし解析は 実験と比べて(2)の変位が若干小さく、(3)の変位が若干大きい傾向が 見られる。

実験の最終時の上弦材の座屈状況を写真一1に示し、解析の最終 時の変形を図一 5 に示す。解析の変形は、立面のみを示し、変形倍 率を1.0とした。また $\mathrm{A} \sim \mathrm{C}$ の各詳細では便宜的に側面の主トラス を太線で示した。なおこれらの図は、実験の最終時よりも全体の変 形が進んだ時の結果を示したが、実験の変形状態との定性的な比較 には支障はない。図を見ると、左右対称だった骨組が大きく変形し、 部材が著しくたわんだ様子がわかる。変形図 $\mathrm{A}$ 詳細の側面の主トラ ス (太線) は写真一 1 (b) と非常に良く似ており、解析でも実験と同様 に、連続した上弦材が上下方向に連成座屈したことを示寸。ただし 実験では連成座屈が水平方向のものや上下逆方向のものも若干見ら れたが（写真－1(a)）、解析のA詳細は全てほぼ同方向であった。 なお実験で座屈方向がばらついた理由には、製作に伴う形状不整や 部材接合時の残留応力なども考えられるが詳細は不明である。

実験および解析の損傷部位を図ー6(a)および (b)に示す。実験の

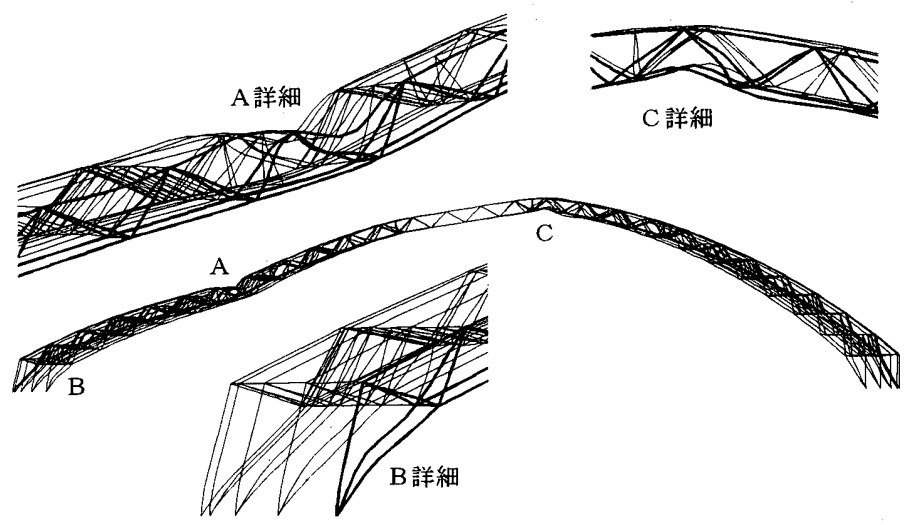

図 -5 解析の変形図（立面、1倍）

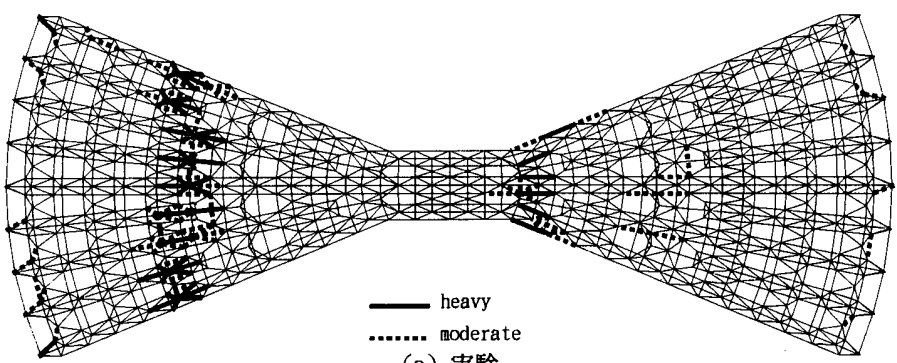

(a) 実験
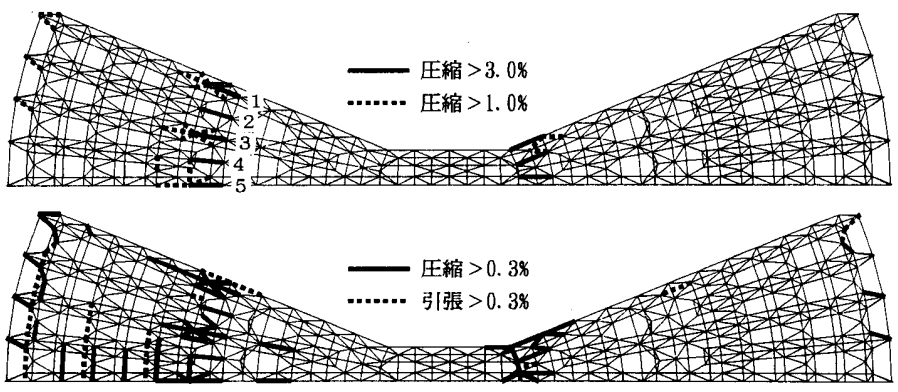

(b) 解析

図 -6 損傷部位の比較（非対称鉛直力試験） 
損傷 ${ }^{33)}$ は目視により、最終時の横たわみが著しい部材を太線で、 やや大きな部材を太破線で示した。解析の損傷は等価軸歪（軸変位 ／初期材長）の大小から定め、等価軸歪が圧縮側に3\%および1\%以上 の部材を図(b)の上図に太線および太破線で示し、等価軸歪が圧縮 側㧍よび引張側に0.3\%以上の部材を同図の下図に太線および太破線 で示した。なお等価軸歪が引張側に1\%以上の部材はなかった。また 解析の損傷部位を等価軸歪ではなく横たわみで定めた場合は、等価 軸歪が圧縮の損傷部位とほぼ一致した。図 (a)、(b)の比較から、解 析の損傷部位は実験と良く対応していると判断される。ただし解析 で上弦材が座屈した付近（図中やや左側）の損傷部位は、場所にも よるが実験に比べて若干右寄りの傾向が見られる。これは図－4の 荷重一変位曲線の(2)(3)において実験と解析が若干相違した事と関係 があろう。なお損傷部位付近では下弦材の本数が減じているが、上 弦材の本数には変化がなく、実験と解析の損傷部位の若干の相違を 簡単には説明できない。ただし解析において、下弦材の数が減じた 主トラスの上弦材（図(b)の上図に2、4で示す材）が連成座屈になっ ていない現象は、下弦材の数が減じた位置でラチス材長が短く、ラ チスによる拘束が大きいためと考えられる。

\section{3 弦材の連成座屈の検討}

図一7に連成座屈した上弦材の軸応力度（軸力／断面積）と等価 軸歪の関係を圧縮を正にして示寸。図中の3本の実線が側から $1 、 3 、 5$ 番目の上弦材（位置を図-6(b) 中に示す）を示し、破線が2番目の 上弦材を示す。連成座屈の関係で、これらの上弦材 (以下、当該材 と記す）と連続する上弦材（以下、連続材と記す）の結果も併せて 示した。なお側から4番目の結果は2番目と差がなかったので省略し た。図から以下のことがわかる。i）1、3、5番目 (実線)では当該材が 軸方向に大きく縮んだが、連続材もいくらか縮んでいる。ii）当該 材で図中の曲線が他と比心゙下にある場合、連続材の曲線が他と比心゙

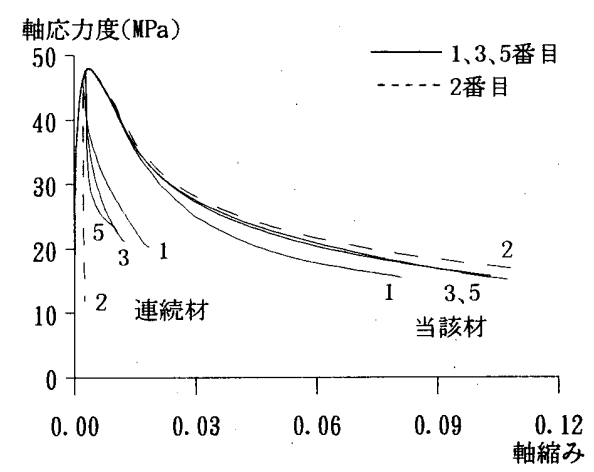

図 -7 上弦材の軸応力度と軸縮みの関係 上になる補完的な傾向が見られる。iii）1５番目の当該材の座屈荷 重には注とんど差がなく、ある当該材の座屈が隣の主トラスの当該 材の座屈荷重を低下させるような立体効果はなかったと推察される。 iv)2番目 (破線)では、連続材がほとんど座屈せずに除荷されている。 なお1〜5番目の軸力を合計すると、当該材と連続材でほとんど差が なかった。また当該材の座屈順序は側から $1 \rightarrow 2 \rightarrow 3 \rightarrow 4 \cdot 5$ 番目の順で あった。

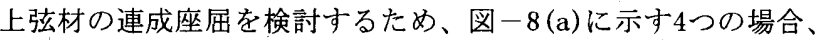
(1)：雨端固定で座屈する場合、(2)：2連続した材が中間で回転を拘 束されて、1端ピン他端固定と同じ座屈をする場合、(3)：2連続した 弦材が中間で4本のラチスにより横たわみと回転を拘束されながら 座屈する場合、(4)2連続した弦材と8本のラチスからなる部分モデル の弦材が座屈する場合、について軸応力度と等価軸歪の関係を調心゙ た。ただし(3)(4)では、図中に破線で示した底面を剛とし、底面の変 位注図中矢印方向の並進だけを許容した。また骨組解析の連成座屈 が上下方向だったことから、弦材の水平方向の座屈を拘束した。初 期不整は図中右側および左側の弦材に下および上向きの $1 / 10000$ 初 期たわみを仮定した。得られた軸応力度と等価軸歪の関係を図 -8 (b)に示す。上および下にある破線はそれぞれ(1)両端固定および(2) ピンー固定の結果を示す。1点鎖線および実線は(3)ラチスー固定お よび(4)部分モデルの結果を示す。ただし1点鎖線および実線は各2本 あり、上にある線 (図中R)が右側の、下にある線 (図中L)が左側の弦 材の結果を示す。なお(1)および(2)で部材をより細かく分割した平面 解析結果を点線で示すが、軸縮み5\%以下だと部材モデルの結果 (破 線)とほとんど変わらない。図から、(3)ラチス一固定で恃左右の弦 材 (2本の1点鎖線)であまり差がないが、(4)部分モデルでは左右の弦 材 (2本の実線)の軸応力度一等価軸歪関係に大きな差が生じたこと がわかる。この原因として、(3)のモデルは左右の弦材軸力がほぼ等 しくなるのに対し、(4)のモデルでは追加したラチスにより弦材の軸 力差が許容される事が考えられる。なお(3)と(4)で座屈荷重にはほと んど差がない。

図-8(c)に、骨組解析の側から3 番目の結果 (図一7中の3の実線) を実線で、(4)の結果を一点鎖線で比較して示す。また図中には(1)お よび(2)の結果を破線で併せて示した。図から以下のことがわかる。 i) (4)部分モデルの両弦材の結果 (2本の一点鎖線) は骨組中の連成座 屈の結果 (2本の実線) とほとんど一致した。ii) 耐力低下域では当該 材の結果 (上の実線) が(1)両端固定の結果 (上の破線)に近く、連続材 の結果(下の実線)が(2)ピン一固定の結果(下の破線)に近い。したが って本解析の連成座屈は、(4)部分モデルによりモデル化できるが、

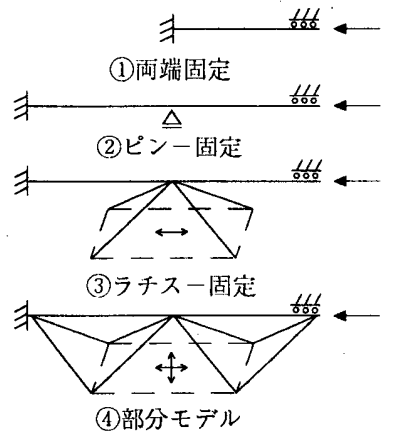

(a) 検討モデル

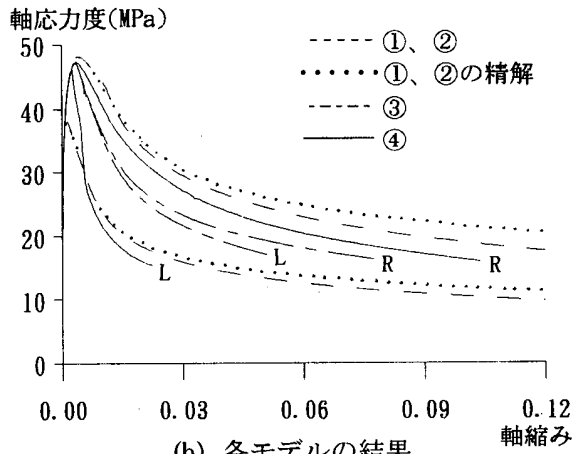

(b) 各モデルの結果

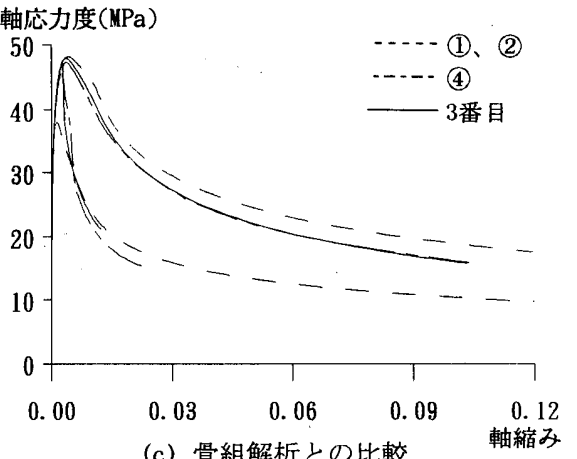

(c) 骨組解析との比較

図 -8 軸応力度一軸縮み関係の検討 
座屈荷重は(3)ラチスー固定の場合とほぼ同じで、耐力低下後の軸力 一軸変位関係は当該材が(1)両端固定に、連続材が(2)ピン一固定にそ れぞれ近かったことがわかる。

\section{4. 直交方向試験の解析 \\ 4. 1 実験概要}

直交方向試験は、非対称鉛直力試験と同じ試験体を作成して、ス パン直交方向に繰り返し水平力を作用させた試験である。詳細は文 献 ${ }^{14)}$ に詳しい。荷重分布はスパン方向にほぼ一様で、試験体の加 力方向手前の側面にある計16の載加点にトーナメント方式で加力し た。ただし解析では、簡単のため加力方向に関係なく正負両側の全 載加点 (32点)に載加した。加力サイクルは試験体頂部のスパン直交 方向変位がスパンの $\pm 1 / 1000 、 \pm 1 / 500 、 \pm 1 / 200 、 \pm 1 / 100 k$ 達し た時点で各1回ずつ繰り返し、最後は正側に加力している。

\section{2 解析結果および実験との比較}

実験結果がほぼ対称だったことから、解析は $1 / 2$ モデルで行った。 実験および解析の荷重と頂部水平変位の関倸を図一-9に示す。実線

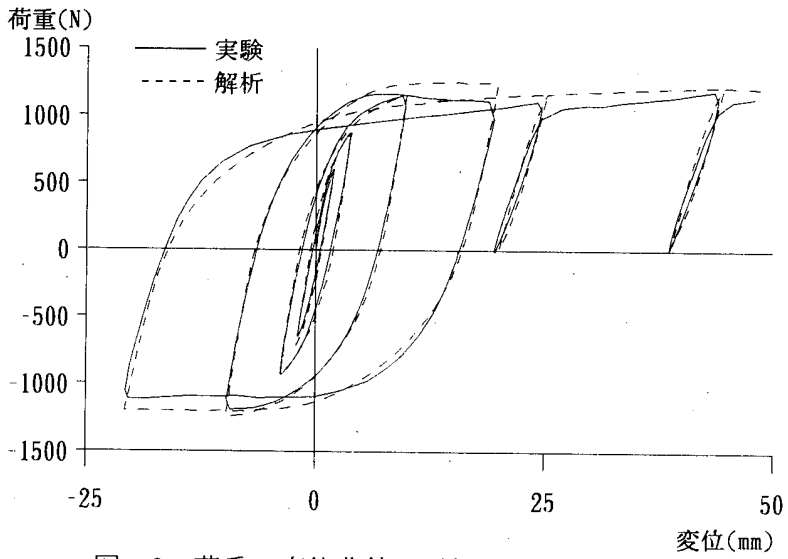

図-9 荷重一変位曲線の比較（直交方向試験）

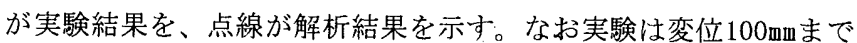
行ったが、解析は変位 $50 \mathrm{~mm}$ を越えると荷重一変位関係にいくらか振 動が見られたので変位 $50 \mathrm{~mm}$ までとした。図を見ると、変位の大きい サイクルでは解析結果が実験結果を若干上回るものの、解析は実験 と良く一致している。最大荷重は実験值の正側1160N、負側1190Nに 対し、正側が1250N、負側が $1240 \mathrm{~N}$ と解析值の方が4 8\%程度大きい。 なお実験では、試験体の巨視的な崩壊形が、最初の主要な損傷であ るラチスの座屈には関係せず、後で見られた柱脚直上部の主トラス の巨視的な曲げ降伏によると推察されている ${ }^{14)}$ 。したがって実験 の荷重低下は前者の耐力低下と後者の耐力上昇を合わせた結果であ り、実験と解析の耐力低下の有無を比較しても特別の意味はない。

図ー10に実験および解析の沈下量を実線および破線で示す。ただ し沈下量は、中央やや上部（図中）における球中心方向への変位 とし、横軸は頂部水平変位とした。解析でも実験と同様に、繰り返 し載加によって沈下量が増大したことがわかる。解析を実験と比べ ると、+4サイクルで生じたずれを除くと、両者は非常に良く対応す ることがわかる。

実験の変形状況を写真－2に示し、解析の最終時 (変位50mm時) の 変形を図ー11に示す。なお写真は (a) が変位 $100 \mathrm{~mm}$ 時、(b) が変位 40 mm時のものである。図 (a) は解析の変形をスパン方向 $45^{\circ}$ 上方から見 たもの、図(b) は側面から見たものを示寸。図(c) は脚部の斜視図で あるが、手前の主トラスだけを太線で示した。解析の変形を写真と 比べると、制御変位の大きさが異なるものの比較ではあるが、図 (b) は写真 (a) と、図 (c)の太線は写真 (b) と極めて良く似ていることが わかる。

実験および解析の損傷部位を図ー12(a)および(b)に示す。ただし 実験の損傷は、+3、+4サイクルで横たわみが顕著となった部材を太 線で示し、最後の正側加力で横たわみが顕著となった頂部付近の部 材を太破線で示した。解析の損傷は、図 (b)の右図が最終時に圧縮 側または引張側で等価軸歪が0.3\%以上の材を示し、左図が圧縮側で 等価軸歪が $1 \%$ ・3\%以上の材を示す。なお引張側で等価軸歪が $1 \%$ 以上

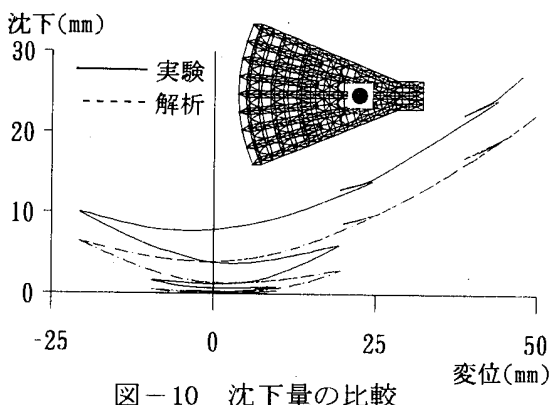

図-10 沈下量の比較

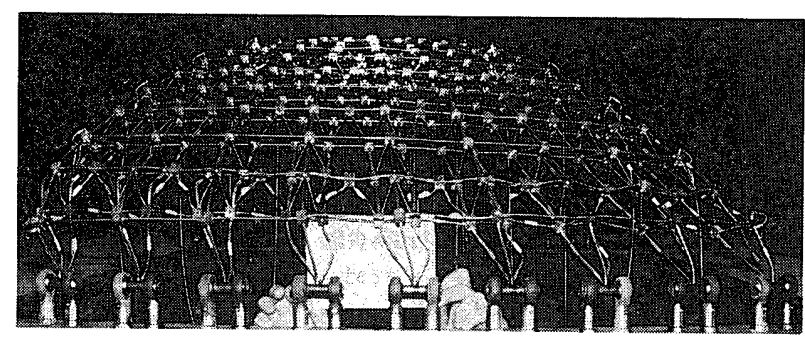

(a) 側面全景(変位100wu時)

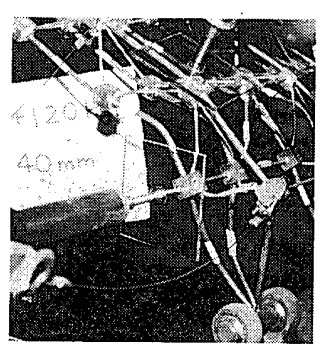

(b) 脚部詳細 (変位40mm時) 写真 -2 実験の変形状況

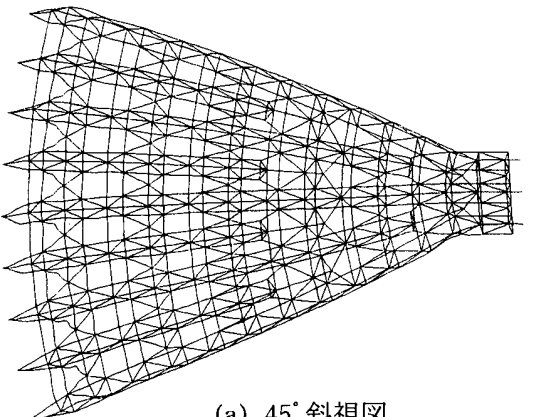

(a) $45^{\circ}$ 斜視図

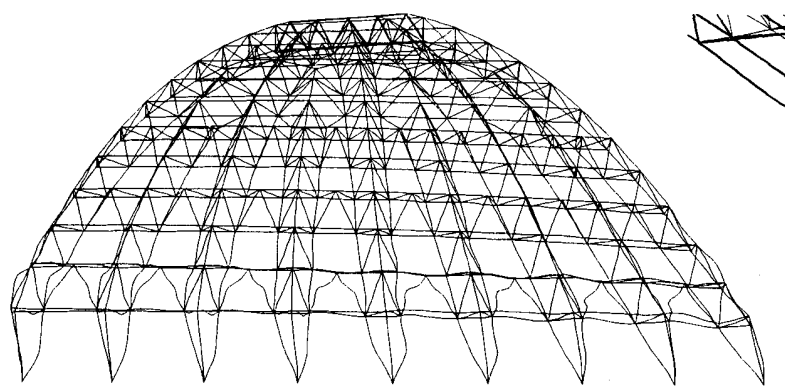

(b) 側面図

図 -11 最終時の変形図 (変位50mm時、1倍) 
の材は図示しないが3つと少ない。解析の損傷を実験と比心゙ると、 実験最終時の変位が解析の 2 倍であることを考えれば、解析の損傷 は実験と良く対応していると言える。

\section{3 . 解析での弦材の座屈}

損傷が大きかった脚部付近の下弦材のうち、その位置を図ー11(c) および図ー12(b) 中に $a, b$ で示す連続した材（以下では $a$ 材、b材と呼 ぶ）の挙動を図一13に示寸。な扮a材の公称断面は $\phi-3.5 \times 0.5 、 b$ 材 は $\phi-3.5 \mathrm{x} 0.3$ であり、a材の方が管厚が大きい。a材および 応力度と等価軸歪の関係を図-13(a)に実線および2点鎖線で示す。 また同図(b)および(c)に、a材およびb材の両端(剛域内端)の等価曲 げ応力度（曲げモーメント／塑性断面係数）と等価軸歪の関係をそ れぞれ示す。ただし図(b)，(c)では実線がトラス全体をシェルとし て見たときの面外方向への曲げ（下に凸な側を正）を示し、2点鎖 線が面内方向への曲げ（平面図で見て上に凸な側を正）を示す。図 -13から以下の事がわかる。i）図(a)の座屈軸忍力度は、a材が35 $\mathrm{MPa}$ で1端ピン他端固定の解析值 $38 \mathrm{MPa}^{13)}$ に近く、b材はサイクルに もよるが57〜63MPa と両端固定の解析值 $61 \mathrm{MPa}^{13)}$ に近い。ただしこ れに断面積を乗じた座屈軸力は、 $\mathrm{a}$ 材とb材の差が1割以下と小さい。 ii +4 サイクルでは主にb材が大きく座屈して軸応力度が低下した (図 (a)の2点鎖線)。ii )この時のb材の面外の曲げ応力度は両端 でほぼ等しく（図(c)第三象現の2実線）、両端固定に近い状態で連

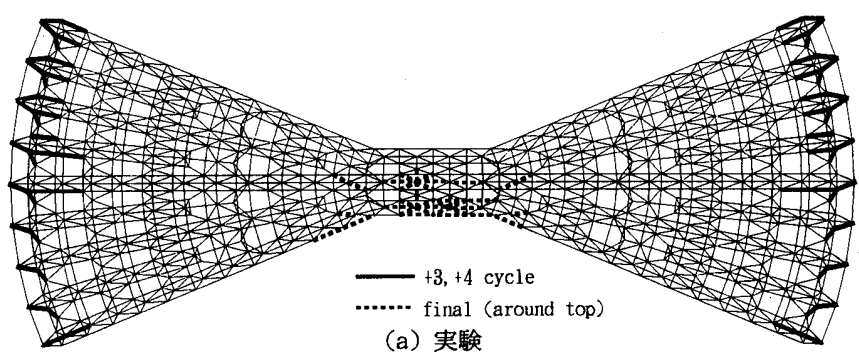

(a) 実験

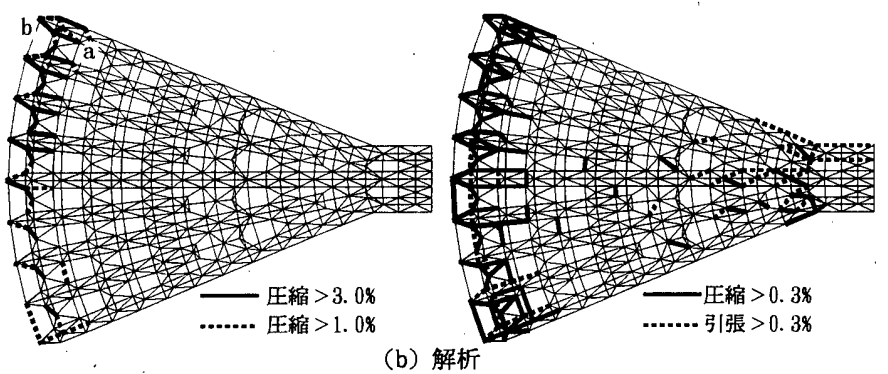

図-12 損傷部位の比較（直交方向試験） 成座屈したと考えられる。iv)-4サイクルではb材に大きな引張軸力 が作用して（図 (a)の2点鎖線）、座屈と逆方向に大きな曲げが生じ た（図 (c) 第二象現の 2 実線）。v)この関係で、b材は最後の+5サイ クルの座屈荷重が+4サイクルと比べて低下せず（図（a）の2点鎖線）、 最後の+5サイクルでは逆にa材の座屈が大きく進んだ（図 (a)の実線) と考えられる。なおa材では、引張軸力による曲げ戻しが顕著でな く(図(b)の2実線)、繰り返しによる座屈軸応力度の低下が認めら れる（図(a)の実線）。

\section{5. 結論}

過去に提案した立体骨組の複合非線形解析法に若干の変更を加え て、大規模立体トラス模型実験に対する複合非線形解析を行った。 非対称鉛直力試験 ${ }^{13)}$ 、直交方向試験 ${ }^{14)}$ のいずれの実験結果に対し ても、解析結果は大変形領域まで非常に良く一致した。

非対称鉛直力試験に対する解析では、実験で見られたような連続 した弦材の連成座屈を解析でき、座屈の変形状況も実験とほぼ一致 した。連成座屈を検討するため、簡単な部分モデルについて解析し たところ、両弦材の軸力差を許容するようなラチスの存在によって、 連成座屈した両弦材で後座屈挙動に大きな差が生じて、実験および 解析で見られた非対称な連成座屈になることがわかった。

直交方向試験に対する解析では、複雑な実験に伴う測定点数の不 足から、各部材が座屈したのか曲げられたのか実験ではわからなか った脚部の複雑な崩壊状況が解析できた。脚部の弦材の挙動を調べ たところ、素材特性に大きく依存寸ると思われるが、繰り返し載加 により、連成座屈で変形が大きい側の部材が入れ替わる現象が見ら れた。

本解析結果から、全体座屈的な現象を除外寸れば、複雑かつ大規 模な立体骨組に対しても、部材の弾塑性座屈の連成を含めて大変形 領域まで解析できることがわかった。

索考文献

1）水渡明、多田元英：一般化硬化塑性ヒンジモデルと增分摂動法による立 体剛接骨組の複合非線形解析、構造工学論文集 Vol. 41B、pp. 231〜238、 1995. 3

2）柴田良一、加藤史郎、植木隆司 : きわめて扁平な剛接合単層ラチスドー 厶の弾塑性座屈荷重、日本建築学会構造系論文報告集、pp. 143～153、 1993.7

3）加藤史郎、庄村昌明、向山洋一 : 水平と鉛直地震動を受ける大スパン単 層ラチスドームの忘答性状と崩壊加速度に関寸る研究、日本建築学会構造 系論文集、pp. 87〜96、1995. 11

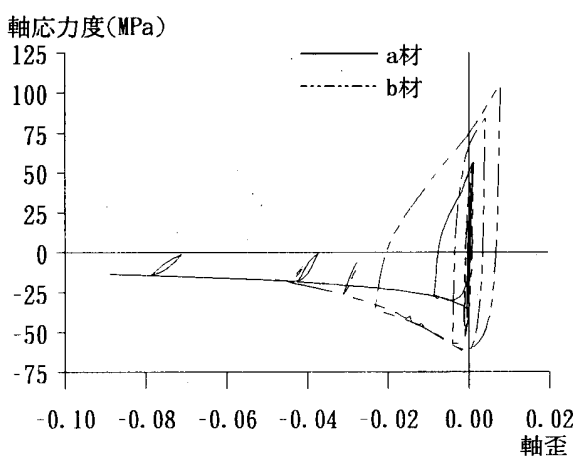

(a) 軸応力度と軸歪の関係

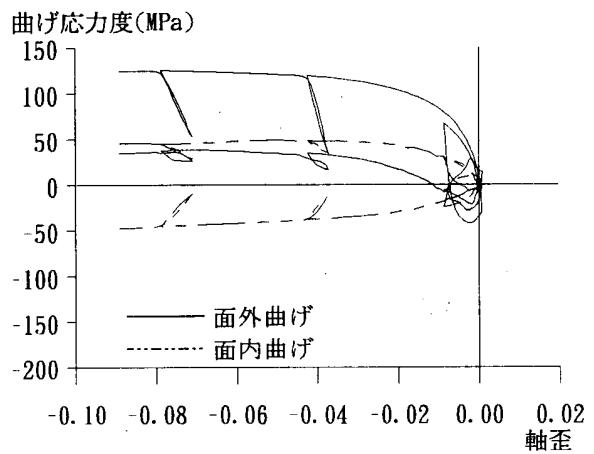

(b) 曲げ応力度と軸歪の関係 (a材) 図 -13 脚部付近の弦材の挙動

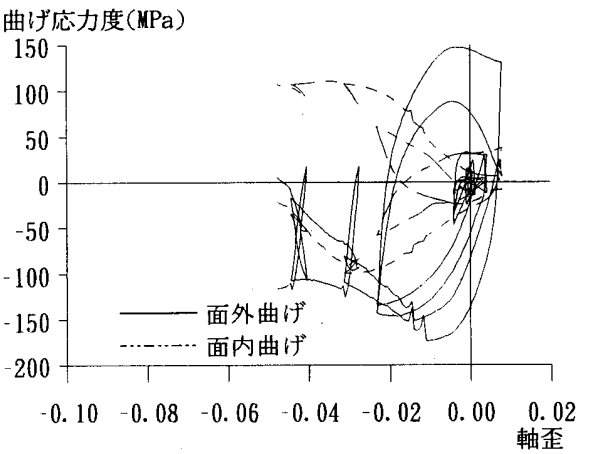

(c) 曲げ応力度と軸歪の関係 (b材) 
4）都井裕、磯部大吾郎：順応型Shifted Integration法による大規模骨組 構造の耐震強度解析、生産研究46巻、pp. 505 508、1994. 10

5）例えば、植木隆司、加藤史郎、向山洋一、松栄泰男: 両端に回転ばねの ある部材で構成される単層ラチスドームの弾塑性座屈荷重、日本建築学会 構造系論文報告集、pp. $47 \sim 58 、 1993.6$

6）鈴木敏郎、小河利行、久保寺勲、五十嵐規矩夫 : ボール接合単層ラチス ドームの座屈実験及び弾塑性座屈解析、日本建築学会構造系論文報告集、 pp. 53 62、1993. 2

7）修行稔、岡延夫、李剣平 : 半剛接接合部を有する銅立体骨組の弹塑性非 線形解析、日本建築学会構造系論文集、pp. 89 94、1996.2

8）北田透、上谷宏二、大崎純：增分摂動法を用いた立体骨組の弹塑性大た わみ解析法、日本建築学会大会学術講演梗概集、pp. 1285 1286、1994. 9

9) Hill, C.D., Blandford, G.E., and Wang, S.T. : Post-Buckling Analysis of Steel Space Trusses, Jour. of Struc. Eng., ASCE Vol.115, pp.900-919, 1989.4

10）和田章、向秀元：一方向大スパン復層円简トラス構造物の地震忘答解析、 日本建築学会構造采論文報告集、pp. 87 96、1990.7

11）多田元英、米山達也 : 建築物の屋上に設置された2層立体トラスの鉛直 地震応答性状、日本建築学会構造系論文報告集、pp. 77 86、1993. 10

12）石川浩一郎、加藤史郎：二層立体ラチスドームの上下地震時耐震性能の 及ぼすドーム付加荷重の影響、日本建築学会構造系論文集、pp. 119〜127、 1995. 9

13）堀昭夫、島崎和司、和田章 : 非対称鉛直力を受ける大スパン2層立体卜 ラスの静的模型実験、日本建筑学会構造系論文報告集、pp. 105 113、 1992. 6

14）堀昭夫、島崎和司、和田章 : スパン直交方向水平力を受ける大スパン2 層立体トラスの静的模型実験、日本建築学会構造系論文報告集、pp. 73 82、1993.2

15）上谷宏二、中村恒善、森迫清貴、石田修三 : 弾塑性構造物の臨界挙動解 析のための整合剛性行列形成法、日本建築学会構造系論文報告集、pp. 67 $\sim 78 、 1993.3$

16）森迫清貴、石田修三、上谷宏二：弾塑性骨組の臨界举動解析に抢ける整 合剛性行列、第43回応用力学連合講演会、pp. 111 114、1994. 1

17）堀昭夫、笹川明：試行的な㓮性選択法を用いた1次元有限要素法による 立体骨組の複合非線形解析法、日本建築学会構造系論文集、1996.12(掍載 予定)

18）堀昭夫、宇野哲生ほか：リボン形平面の屋根を有する開閉ドームの試設 計 (その1〜3)、日本建築学会大会学術講演梗概集、pp. 1337〜 1342、 1990. 10 